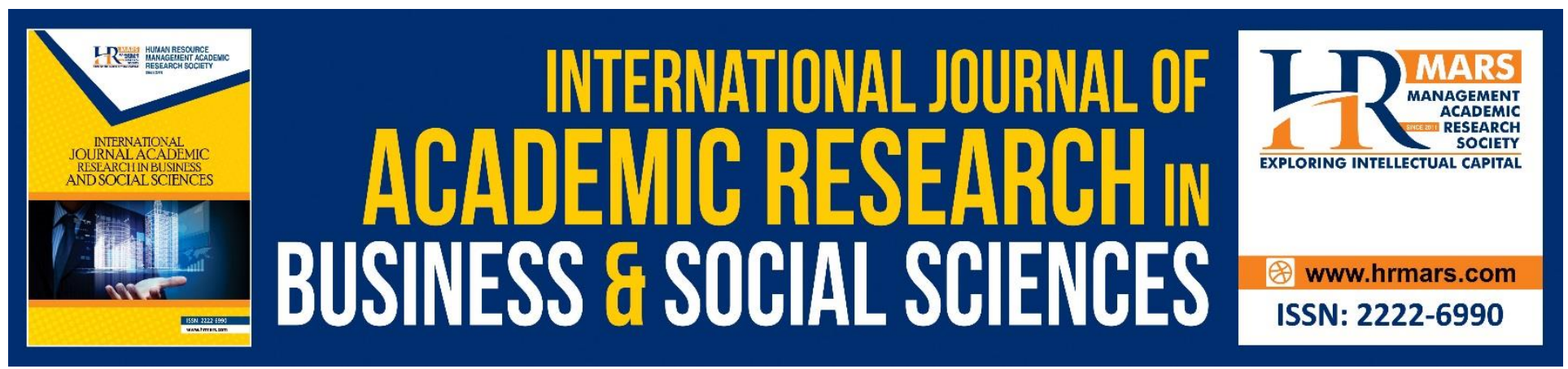

\title{
Entrepreneurship: An Engine for Economic Growth
}

\author{
Promise Zvavahera, Farai Chigora, Roselyn Tandi
}

To Link this Article: http://dx.doi.org/10.6007/IJARBSS/v8-i11/4884

DOI: $10.6007 /$ IJARBSS/v8-i11/4884

Received: 21 Sept 2018, Revised: 15 Oct 2018, Accepted: 03 Nov 2018

Published Online: 23 Nov 2018

In-Text Citation: (Zvavahera, Chigora, \& Tandi, 2018)

To Cite this Article: Zvavahera, P., Chigora, F., \& Tandi, R. (2018). Entrepreneurship: An Engine for Economic Growth. International Journal of Academic Research in Business and Social Sciences, 8(11), 55-66.

Copyright: (C) 2018 The Author(s)

Published by Human Resource Management Academic Research Society (www.hrmars.com)

This article is published under the Creative Commons Attribution (CC BY 4.0) license. Anyone may reproduce, distribute, translate and create derivative works of this article (for both commercial and non-commercial purposes), subject to full attribution to the original publication and authors. The full terms of this license may be seen at: http://creativecommons.org/licences/by/4.0/legalcode

Vol. 8, No. 11, 2018, Pg. 55 - 66

http://hrmars.com/index.php/pages/detail/IJARBSS

JOURNAL HOMEPAGE

Full Terms \& Conditions of access and use can be found at http://hrmars.com/index.php/pages/detail/publication-ethics 


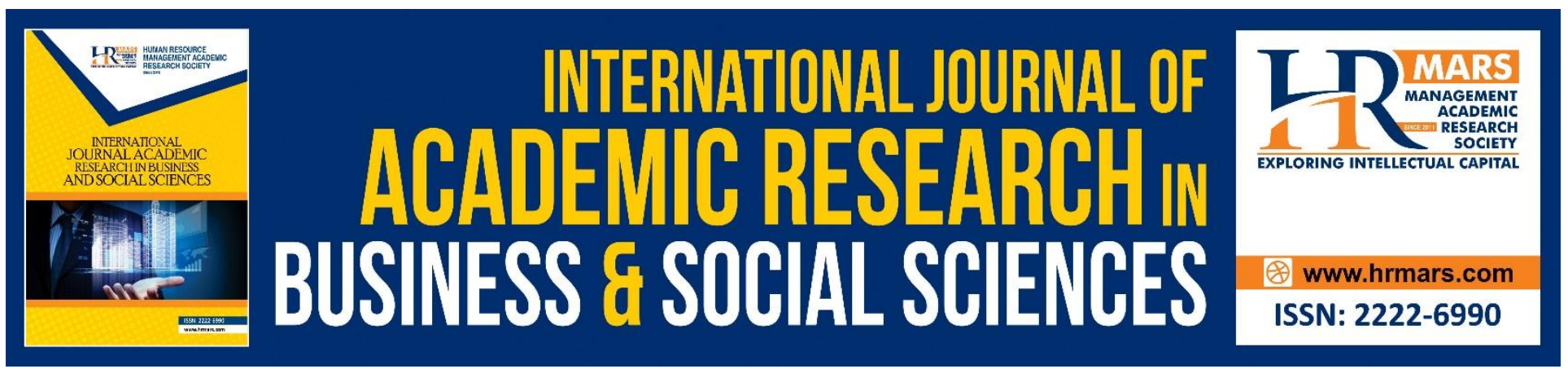

\title{
Entrepreneurship: An Engine for Economic Growth
}

\author{
Promise Zvavahera \\ (Corresponding Author) \\ Reformed Church University, Faculty of Commerce \\ Email: promisezvavahera59@gmail.com \\ Farai Chigora \\ Catholic University of Zimbabwe \\ Email: fchigora@yahoo.com \\ Roselyn Tandi \\ Catholic University of Zimbabwe \\ Email: rtandi@cuz.ac.zw
}

\begin{abstract}
This study was carried out to evaluate the impact of entrepreneurship on the socioeconomic development of the Zimbabwean economy with the aim to have an insight on whether it is a policy for socio-economic reform or a gimmick to sale the nation's brand to the world. The study was carried over five months in five different entrepreneurial organisations. Face-to-face interviews and documentary analysis were used to gather data. The study found that entrepreneurship indeed, create wealth and employment for the majority of Zimbabweans. It was noted that entrepreneurship was contributing to economic growth, through paying taxes to the government and creating employment in comparison to mere branding of the nation. All the participants indicated that recapitalisation of their businesses was a major concern since there were no lines of credit from the local banks and financial institutions justifying that the Entrepreneurship drive in Zimbabwe is real but not a smoke screen for national branding. They also bemoaned restrictive investment policies and legislation in the country. It was also found that the Government was not supporting the growth of entrepreneurial organisations which to some extent reflects the policy the government to be more of self-branding rather than societal empowerment. The study concluded that entrepreneurship is a critical vehicle for creating employment and growing the Zimbabwean economy. The study recommended that financial support, capacity building and enhancement and a supporting legal framework were critical for the formation, survival and growth of entrepreneurial organisations in Zimbabwe.
\end{abstract}

Keywords: Entrepreneurship, Growth, Risk, Opportunities, Leadership 
INTERNATIONAL JOURNAL OF ACADEMIC RESEARCH IN BUSINESS AND SOCIAL SCIENCES

Vol. 8, No. 11, Nov, 2018, E-ISSN: 2222-6990 @ 2018 HRMARS

\section{Introduction}

A plethora of problems has led to the poor performance of the Zimbabwean economy. This further led to downsizing and closures of most companies leaving many people unemployed (Raimi, 2011). This led to the proliferation of small-medium enterprises across the country, most of them not formally registered. The continued poor performance of the economy was attributed among other things to unfavourable polices for investors and high interest rates among others (Kanyenze \& Kondo, 2011). These businesses have not been contributing to the GDP of the country due to a number of challenges. In order to address its economic woes, the Zimbabwean Government with the assistance from the World Bank and the International Monetary Fund introduced the Economic Structural Adjustment Programme (ESAP) in the early 1990s. The aim of ESAP was to reduce government expenditure, remove subsidies and improve economic performance of the country (Zvavahera, 2014). This together with the Fast Land Reform Programme of the year 2000 and sanctions imposed on the country by the West further deteriorated the economy. The then Ministry of Small and Medium Enterprises and Cooperatives Development which was integrated with other ministries after the 28 November 2017 Operation Restore Legacy, was created to promote entrepreneurial organisations through funding and capacity building and enhancement. The mandate of the Ministry was to stimulate economic growth, create wealth and employment opportunities and promote sustainable economic growth through small-medium enterprises. Nani and Radipere (2016) aver that the Zimbabwean economy has been gripped with high unemployment rate which is estimated to be around 90\% (Chenga, 2013).

\section{Literature Review}

Entrepreneurship plays a significant role through creating employment, providing goods and services to the poor and is regarded as an important hedge against poverty (Chigwenya \& Mudzengerere, 2013). Entrepreneurship has been in existence since time immemorial and it is a continuous process inclined with change for better business conduct and results which are customer oriented (Pirich, 2001). In the early days, entrepreneurship was associated with manufacturing, black smiths, weavers and many other activities. Entrepreneurship started to make some impact during the Great Recession of the 1930s when many organisations came up with improved techniques of production to meet their clients' growing needs and demands. Entrepreneurship is a way of thinking, reasoning and acting that is opportunity obsessed, holistic in approach and leadership balanced. It is the process of committing all resources and energies towards a business idea (Hisrich, Peters, \& Shepherd, 2007). It can further be regarded as a process of identifying and grabbing a business opportunity for future benefits. In some countries, such organisations are known as start-up companies as they will still be new on the market trying to find space from competition. Entrepreneurship in a large organisation can be referred to as intra-preneurship. Entrepreneurs are there to make a difference in the way business is done. Entrepreneurs do not incline themselves to the past, as they are obsessed with new ideas and opportunities. It is about enhancing organisational creativity and putting failure into perspectives (Zimmerer and Searborough, 2006). Entrepreneurship can help the creation new jobs in distressed economies such as the Zimbabwean economy. Entrepreneurship is concerned with the creation, enhancement, realisation and renewal of value for all stakeholders. The creation and recognition of opportunities is at the heart of entrepreneurship. It 
involves the willingness to take both personal and financial risks, with the purpose of shifting the odds in favour of the entrepreneur. Small-medium and large firms such as Microsoft, Apple and many others are all forms of entrepreneurship which have grown to global conglomerates.

It has been noted that small and medium sized enterprises are the main drivers of job creation, economic growth and social fibre of Europe. Europe's GDP (60\%) is contribution from entrepreneurial organisations. Entrepreneurial activities vary in nature and size. These range from individual enterprises to joint-venture organisations. These can be undertaken on a full-time or parttime basis. The European Commission notes that Europe needs more entrepreneurs than before to steer up economic growth. It is further noted that around 4 million jobs are created every year as a result of entrepreneurial organisations being created through support from their government. It has been noted that educating citizens about entrepreneurship increases the opening of new companies and creation of jobs. Entrepreneurship is likely to be successful under the following conditions:

- When a financing vehicle is available;

- When government support ventures in their initial stages through enabling; legislation and capacity building; and

- When information and communication technology is available to support the growth of entrepreneurial organisations (Commission of the European Communities, 2003).

On a study that was carried by the European Commission (2003), it was noted that 4 out of 10 Europeans were prepared to become their own bosses if they were supported. Thus, the main goal of entrepreneurship is to pursue growth while generating wealth, employment and social good for the society. The authors view entrepreneurship as continuous process of innovation and nurturing an enterprise with financial resources to see the vision through. The idea of enterprising is wealth creation. Entrepreneurship has played an important role in economic growth, innovation and competitiveness and in future may be integral to poverty alleviation in most developing countries. What has been noted is that developing and developed countries are at different economic platters and there is need for governments and the private sector to come up with deliberate policies that support entrepreneurial organisations (Muraya, 2004).

\section{Role of Entrepreneurship in Economic Development}

Entrepreneurship is not only there to increase per capita output but also grow the economy through increased output, which allows more wealth to be shared among participants. Innovation is key to entrepreneurship success (Hisrich; Peters; Shepherd, 2007). Lack of understanding of the product-evaluation process is the problem. This is however, can be achieved through innovation and commercialisation which can stimulate economic growth. For innovations to be successful, they need to be unique and add value to the customers and the industry at large. Entrepreneurship is regarded as being innovative, generator of new progressive processes and business ideas. A successful entrepreneurship should exhibit good leadership qualities, management ability and team building skills.

The importance of the entrepreneurship is that it now employees on average $50 \%$ of the the work force in Sub Saharan Africa (Onyenechere, 2011). For instance, in Nigeria 27.3\% of the urban work force is made up of those who are employed in entrepreneurial organisations. Malte (2008) avers that around 4.1 million workers around the world are employed in the the small-medium 
organisations and the number is still growing. According to Jelili and Adedibu (2006), this form of business is here to stay. Ncube (2000) submits that the entrepreneurial organisations in Zimbabwe have failed to absorb all the job seekers. The existence of the small-medium enterprises has helped with creation of employment and alleviation of poverty (Skinner, 2009; Muraya, 2004). For instance, some countries like Kenya have out-grown the formal sector in both employment figures and their contribution to the national economy (Ikiara and Ndung'u, 1997). Hall \& Pfeifjer (2000) submit that Dharwai manufactures products from bamboo for the global market. The role played by smallmedium enterprises can no longer be underestimated, as this sector has developed to be the major source of livelihoods for semi-skilled and unskilled workers who could have been otherwise redundant (Onyenechere, 2011; Rukamann, 2007; Dilek 2009. Moyo (2010), in her book 'Dead Aid' submits that even though Africa continues to receive foreign aid, this has failed to uplift lives of the people of Africa. She further submits that Africa needs to find its feet and start coming up with programmes that encourage entrepreneurship and the creation of jobs. She argues that even though aid is necessary in some cases, this cannot assist in writing our economic success stories as Africans, Zimbabwe included. Aid cannot generate employment and give independence to countries and their citizens. With the view of developing entrepreneurship, the government of India undertook the following two critical initiatives:

i) The new Science, Technology and Innovation Policy 2013, which is intended to promote entrepreneurship and science-led solutions for sustainable and inclusive growth. With the implementation of this new policy, the early indications are that India is poised to take a big leap towards innovation-led growth.

ii) The establishment of the National Innovation Council, whose mandate is to coordinate various innovation-related activities (Science, Technology \& Innovation Policy, 2013).

In terms of promoting entrepreneurship in Zimbabwe, this has been the major setback. The current policies do not support small-medium businesses. Zimbabwe is currently ranked 159 among 190 economies in the ease of doing business (World Bank, 2018). Even though there is an improvement from 171 in 2011, this is not encouraging. This is affecting even locals who what to start up their businesses. Some entrepreneurships have bemoaned unreliable electricity supply, inadequate and dilapidated infrastructure and lacking of financing as the major constrains (Goremusandu \& Chapeyama (2017). Figure 1 shows the raking of Zimbabwe on the ease of doing business by the World Bank, 2018. 
Figure 1: Ease of doing business in Zimbabwe

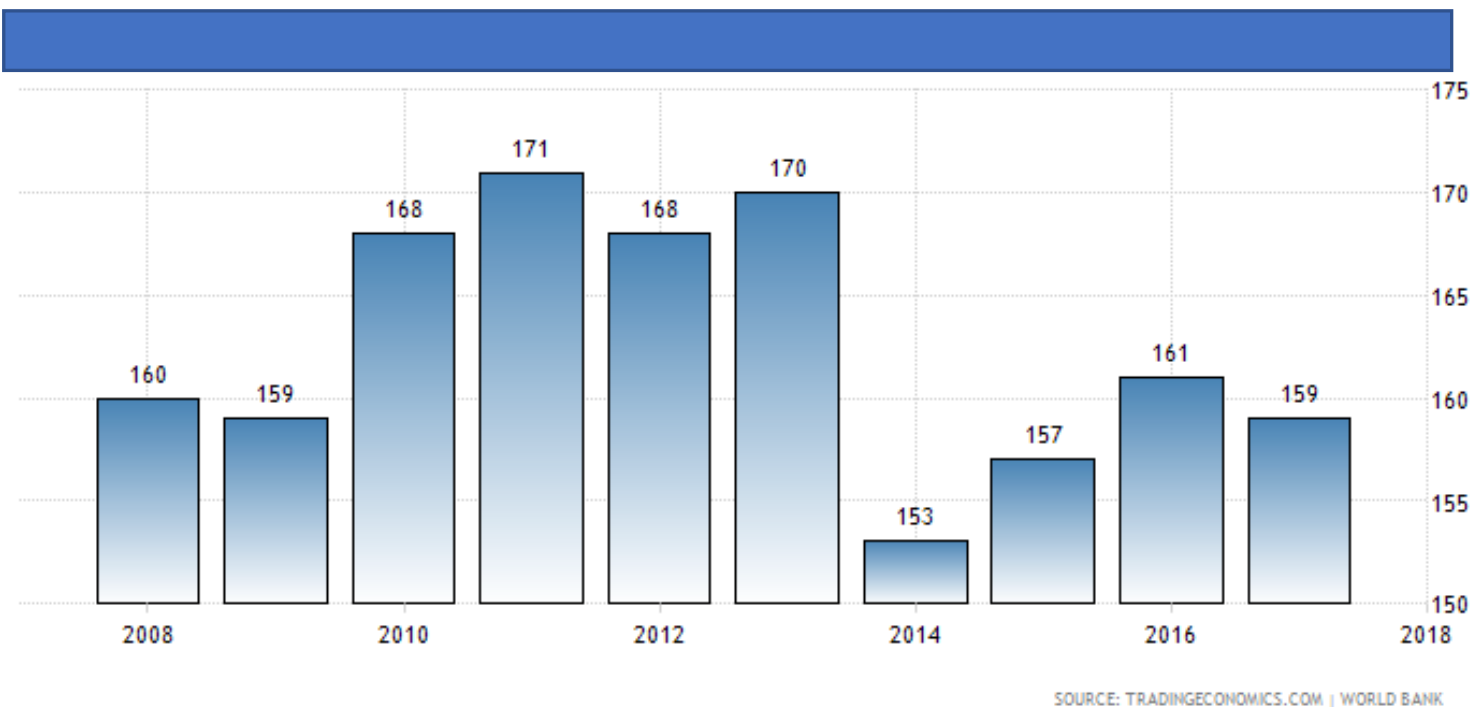

In light of the above mentioned benefits of entrepreneurship and the set-back accompanying application of the same in Zimbabwe, this has added misperception on the beneficiaries. This is because the government has enacted policies for improved entrepreneurship but no much support seem to be given to small business operators. The question now is the policy based on a desire for socio-economic development or a nation branding disguise without any societal gains.

\section{Motivation for Carrying out the Study}

The country has been negatively affected by stagnant economic growth and high unemployment rate. The informal sector is dominating the country's economic activities. According to Kwaramba (2017), the informal sector is the current major employer since most companies have closed down. According to a study carried out by Kumar and Liu (2005), it was found that entrepreneurship contributes significantly to investment, business growth, revenue generation and employment creation. Since entrepreneurship is an engine for economic growth, the government needs to minimise the constraints on entrepreneurship. What is required is to take strong strides in addressing, assisting and empowering entrepreneurs, who now form the majority of trading taking place in the country. The question then is: to what extend can entrepreneurship improve the performance of the economy and create employment?

\section{Research Methodology}

This study used both quantitative and qualitative methods to present and analyse the data. Five entrepreneurial organisations were chosen from the Harare Central Business District. The choice of the five entrepreneurial organisations was based on the African Development Bank Report (2017) on the performance of the Zimbabwean economy. Two organisations are in the the manufacturing sector and the other three in the service industry. 


\section{Population and Sample}

All the employees in the five organisations became the population of the study. Purposive sampling was applied to come up with the respondents. The researchers considered individuals who could provide vital information in this case, the owners/ CEOs of the organisations and senior government officials that included directors and technical officers in the then Ministry of Small and Medium Enterprises and Cooperatives Development. The total number of people employed in these five organisations was one hundred and fifty three (153). Two senior employees from each organisation and four senior government officials were selected to participate in the study. The sample of this study was therefore, 14 participants.

\section{Data Gathering Techniques}

In-depth interviews and documentary evidence were the two methods that were used to gather data from the respondents. These two methods assisted the researchers to validate the data they got from the records in the organisations and what was submitted by the respondents during the interviews. Even though the interviews were time-consuming, they became the researcher's main data-gathering method since the research could ask follow-up questions and the respondents asked for clarity to some of the questions.

\section{Reliability and Validity}

As a way of seeking for the truth, triangulation methods were used in gathering the data. Triangulation is typically a strategy (test) for improving the validity and reliability of research. The researcher used documentary evidence and interviews to solicit information from the respondents.

\section{Findings and Discussion}

The findings of the study are presented in the graph below and these were further used to develop a model that if applied holistically could improve entrepreneurship in Zimbabwe and beyond. These factors were ranked in their order of importance as shown in figure 2. Ten (10) is the highest ranking whilst I is the lowest. All the CEOs/ Owners of these organisations indicated the following as key for developing and nurturing entrepreneurial organisations Zimbabwe.

$>$ Financial support

Policy that supports the creation and growth of entrepreneurial organisations

$>$ Modern technology

$>$ Human capital development.

The issues raised by the respondents are shown in Figure 1 order of their importance. 
INTERNATIONAL JOURNAL OF ACADEMIC RESEARCH IN BUSINESS AND SOCIAL SCIENCES Vol. 8, No. 11, Nov, 2018, E-ISSN: 2222-6990 @ 2018 HRMARS

Figure 2: Frequencies of Responses

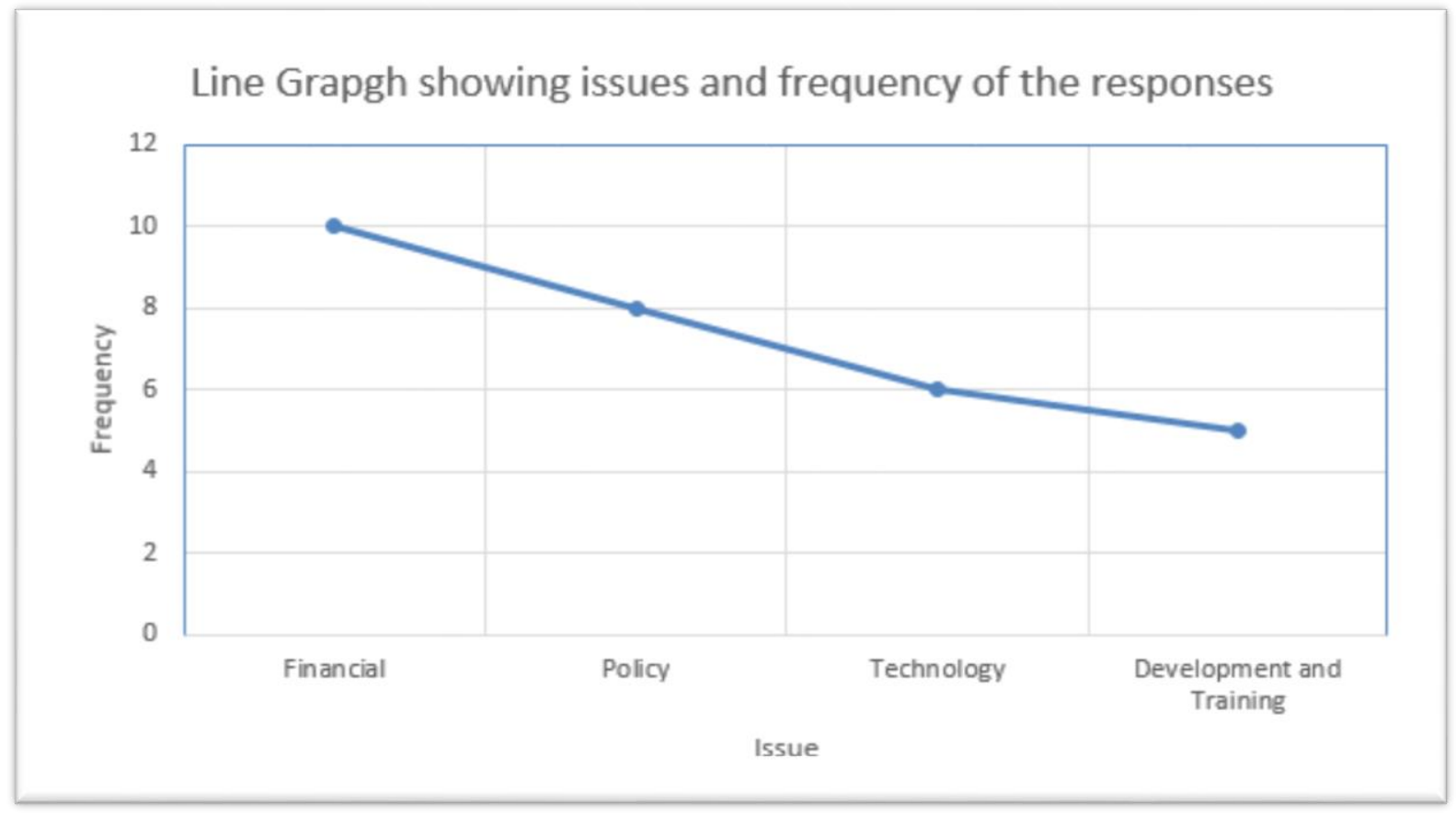

\section{Entrepreneurship Enablers}

Source: Field Data

According to Thompson (2010), entrepreneurship enablers are referred to as individuals who create and develop businesses for socio-economic development. However, according this study, the definition goes beyond to include financial, policy, sustainable and technological initiatives. What is critical for Zimbabwe is to create an environment that allows the domestic and international investment with the major goal of creating of jobs and grow the economy. An approximate labour force of 4 million is is out of employment in the country with a population of 12 million. The creation of jobs by a nation is the most visible measure of success. Creating new jobs is the number one priority need and therefore, the number one benchmark for success. Jobs enable households to fend for their families and stop relying on foreign aid which comes which strings attached as allude to by Moyo (2010). Jobs also broaden the tax base of a nation. The creation of jobs can allow Zimbabwean to move on. Considering the history of Zimbabwe, entrepreneurship is the window of opportunity to create jobs for the people. Entrepreneurs have a direct impact on lives of employees for instance, Econet through Strive Masiiwa has created jobs which have led to the widening of the tax base for the government. Figure 3 shows the linkage of entrepreneurial enablers and how this can be applied to promote economic growth for Zimbabwe. In order to capture the necessities for entrepreneur development, the researcher proposes the following model.

\section{Policy Initiatives}

A number of different pieces of rules and regulations affect the setup and operation of entrepreneurial organisations. Things such as licensing, registration, pollution and and labour laws affect operations of businesses. It is prudent to make sure that laws are 
INTERNATIONAL JOURNAL OF ACADEMIC RESEARCH IN BUSINESS AND SOCIAL SCIENCES Vol. 8, No. 11, Nov, 2018, E-ISSN: 2222-6990 @ 2018 HRMARS

favourable so that sustenance and growth is realised. However, there is also the issue of compliance by organisations to these regulations so that they can freely operate. If these are not adhered to, the business may not be allowed to operate in a country. Issues such as patenting and taxation also affect the entrepreneurship as they are a huge cost to star-up and small organisations. The ease of doing business for the organisation is very critical. On the other hand, if laws in Zimbabwe are not investor friendly, a few people would want to start up businesses. Mechanisms that support the creation and growth of entrepreneurial organisations could go a long way in growing the Zimbabwean economy. Even though entrepreneurs have the zeal to success they lake basic business skills to run their enterprises. It is sad to note that Zimbabwe is currently ranked number 151 out 190 countries in the ease of doing business (World Bank, 2018). This affects domestic and international investors.

\section{Technology and Productivity Initiatives}

The technological initiatives represent the application of icts for achieving the acceptable levels of productivity and quality. In today's business environment, technology has become a critical component of entrepreneurship development. National manufacturing competitiveness is critical for products to be acceptable. In today's organisations, ISO certification is recommended and it can go a long way in promoting the business's endeavours. Organisations in manufacturing need to preach "zero defects zero effect" and those in the service industry need to offer top of the notch service. Delighting the customer is what is important. What has been learnt from this study is that these organisations lack in technology that is important for organisations to meet the expectations of the customers. Information technology allows businesses to be in constant touch with suppliers and their customers. E-commerce is has become a modern way of doing business across the globe. The use of icts have helped businesses such as Amazon and in the case of Zimbabwe, Econet is doing well.

Figure 3: Entrepreneurial enablers

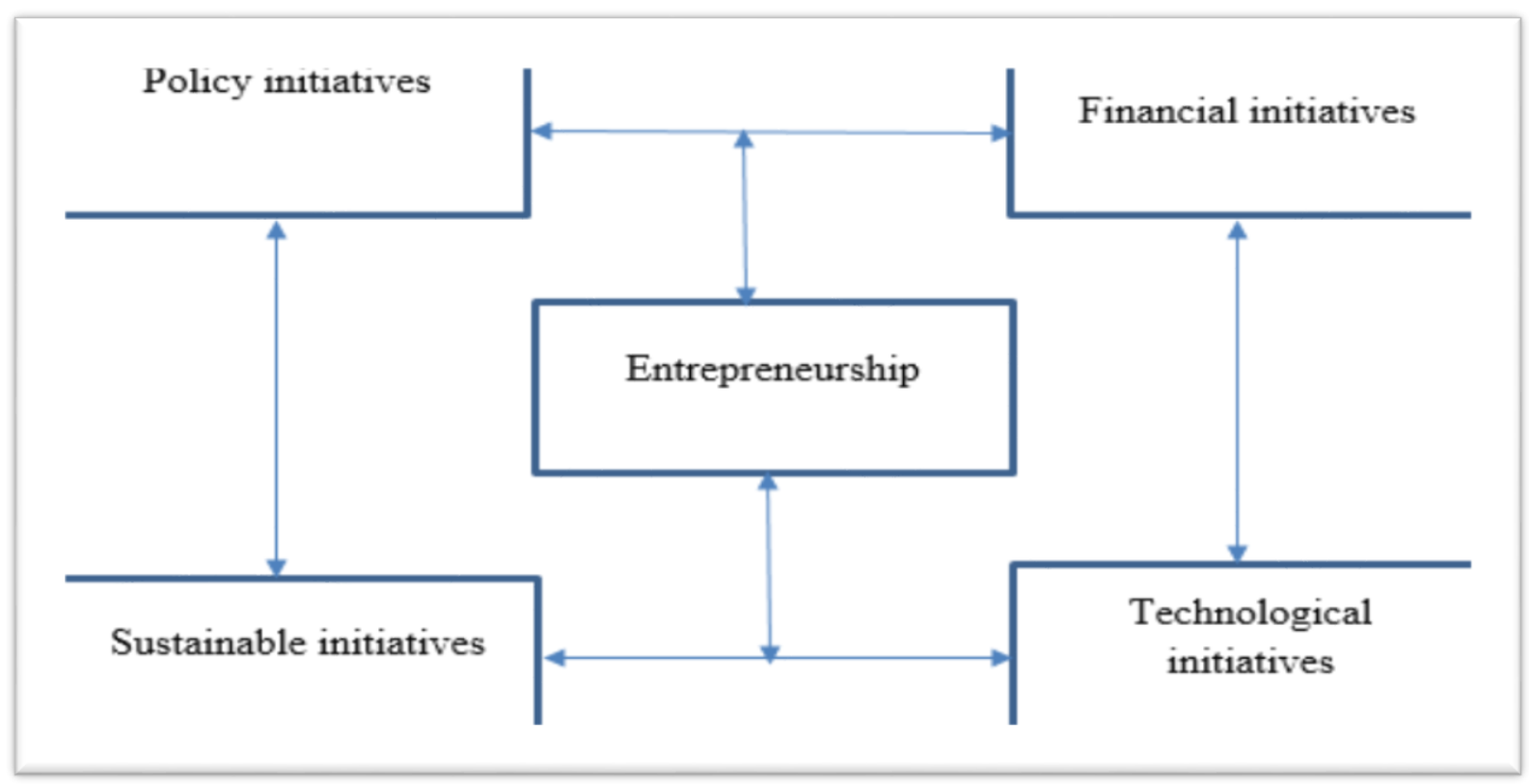

Source: Researchers' conceptual framework 


\section{Sustainable initiatives}

Organisations operating in an ever changing environment. Issues such as globalisation, climate change, social inequality and demographic changes have challenged the traditional way of doing business with the focus now being on shareholder value. All the above issues have a direct impact on entrepreneurial creation, development and survival. For entrepreneurship to develop and be able to create wealth there is need to take cognisance of the following:

$>$ Development of the competencies (skills, experience and attitudes) necessary to recognize a market opportunity and organize the resources to meet it

$>$ Improvement of business performance for growth and competitiveness.

Entrepreneurship orientation and awareness.

$>$ Policies for facilitation

$>$ Public procurement

\section{Financial Initiatives}

Financial vehicles need to be put in place and made accessible to qualifying individuals and organisations. Interest rates and payment periods also need to be favourable. Trade receivables can also go a long way in assisting SMMs grow and contribute meaningfully to the GDP. According to Odero (2016), many SMEs in Zimbabwean are filling due to lack of support from the government and other players. In Zimbabwe two sources of funding exist which are Public (or government) allocation and donor funding. Some organisations have received training funded by the government about the challenge is direct financial injections from either the government or banks to kick-start their businesses. Banks have been reluctant to provide financing due to the instability in economy and lack of collateral security by borrowers.

\section{Recommendations}

Most of the recommendations to be made are targeted at the government of Zimbabwe. In terms of developing and nurturing entrepreneurial organisations, the government is the key player. The Government should support entrepreneurial businesses from start until they graduate to big organisations. It should be noted that financing is one of the key vehicles in supporting entrepreneurship development. The government should create a financial vehicle for entrepreneurs with low interest rates. What has been found out is that most African countries do not have financial vehicles to support startup organisations. The government should put in place policies that support entrepreneurial organisations. Corporations that support entrepreneurial organisations should get tax rebates. Policy synchronisation could also go a long way in promoting entrepreneurship development. Entrepreneurs also need to be trained so that their business do not fail. Zimbabwe has the highest tax regime in the region and lowering this could work as motivator to would-be and existing entrepreneurs. The development of curriculum at primary, secondary, tertiary and higher education levels is key to the development of entrepreneurial organisation in Zimbabwe.

\section{Conclusion}

The study concluded that financial support by the government and key stakeholders could go a long way in making sure that entrepreneurial activities are supported through policy formulation 
INTERNATIONAL JOURNAL OF ACADEMIC RESEARCH IN BUSINESS AND SOCIAL SCIENCES

Vol. 8, No. 11, Nov, 2018, E-ISSN: 2222-6990 @ 2018 HRMARS

that favours the creation and growth of entrepreneurial organisations. In today's business environment, technology is the key driver for economic growth in the world over and Zimbabwe cannot be an exception. is is made possible by making sure that there are sustainable initiatives in place which can can lead to the creation of incubators in key sectors of the economy.

\section{Contribution}

The study is important in that it contributes to the body of knowledge in the field of entrepreneurship in Zimbabwe and beyond. The researchers' conceptual framework in Figure 3, if adopted by the government could assist in promoting entrepreneurial development. Most of the state of development of a country is dependent on the outcome of purposeful human activity in this case, entrepreneurship commitment by the citizens and the government in uplifting the economy. This can also be an eye-opener to the government and other key stakeholders in terms of policy formulation and support.

\section{References}

Chenga, N. (2013). Informal Sector: The major challenge. The Financial Gazette. Available at: www.financialgazezette.co.zw. Accessed on: 07 January 2016.

Chigwenya, A. \& Mudzengerere, F.H. (2013). The small and medium enterprises policy in Zimbabwe: a narrative of strides taken to mainstream the informal sector activities in urban local authorities in Zimbabwe. International Journal of Politics and Good Governance, vol 4, No. 4.

Commission of the European Communities (2003). Entrepreneurship in Europe. http://ec.europa.eu/invest-in-research/pdf/download_en/entrepreneurship_europe.pdf.

Delik, A. (2009). Informal sector offer: Peddling, A paper presented at the first Nordic Conference on service design and service innovation, Oslo, 24-24 November 2009.

Goremusandu, K. \& Chapeyama, P. (2017). Entrepreneurship effects on Zimbabwe's economy. https://www.newsday.co.zw/2017/12/entreprenuership-effects-zimbabwes-economy/.

Hall, P. \& Pfeifjer, G. (2000). Urban future: A global agenda for the 21st Century cities. E. \& F.N. Spon, London.

Hisrich, R.D., Peters, M.P. \& Shepherd, D.A. (2007). Entrepreneurship. $6^{\text {th }}$ Edition. Tata McGrawHill Publishing Company Limited, New Delhi.

Ikiara, G.K. \& Ndung'u N. (1997). The labour market during Adjustment, The case of Kenya, ILO, Geneva.

Jelili, M.O., \& Adebibu, A. A. (2006). Land use classification and the informal sector question in Ogbomoso, Nigeria. Journal of Human Ecology, vol. 20, No. 4, pp. 283-285.

Kanyenze, G. \& Kondo, T. (2011). Beyond the Enclave: Towards a Pro-Poor and Inclusive Development for Strategy for Zimbabwe: Weaver Press. 
INTERNATIONAL JOURNAL OF ACADEMIC RESEARCH IN BUSINESS AND SOCIAL SCIENCES Vol. 8, No. 11, Nov, 2018, E-ISSN: 2222-6990 C 2018 HRMARS

Kumar, S., \& Liu, D. (2005). Impact of globalization on entrepreneurial enterprises in the world markets. International Journal of Management and Enterprise Development, vol 2 (1) pg 4664.

Kwaramba, N. (2017). The role and importance of key entrepreneurship development. The Zimbabwe Independent. May 26, 2017.

Moyo, D. (2010). Dead Aid. Why Aid Makes Things Worse and How There is Another Way for Africa. Penguin Books.

Muraya, P.W.K. (2004). Planning and small-scale enterprises in Nairobi Kenya. Habitat International, www.elsevier.com/locate/habitatint.

Nani, G. \& Radipere, S. (2016). Shape up or ship out. Experiences of micro and small business entrepreneurs in the Bulawayo Metropolitan Province of Zimbabwe. Investment Management and Financial Innovations, 13(2-1), pg173-183.

Ncube, M. (2000). Employment, unemployment and evolution of labour policy in Zimbabwe, Zambezia, vol. 1, pp. 161-194.

Onyenechere, E.C. (2011). The informal sector and environment in Nigerian Towns: What we know and what we still need to know, Research journal of environment and earth sciences, vol 3 , No. 1, pp. 61-69.

Pirich, A. (2001. The interface between entrepreneurship and innovation: New Zealand. SMEs perspective. Paper prepared for 2001 DRU ID Conference, Aalborg, Denmark.

Raimi, L. (2011). "Global economic melt-down and the role of financial institutions: Lessons from South Africa for policymakers in Nigeria", Humanomics, vol. 27, issue 3, pp.201211, https://doi.org/10.1108/08288661111165231.

Rukmann, D. (2007). Urban planning and the informal sector in developing countries, www.indonesiaurbanstudies.blogspot.com/2007/05/urban-planningandinformalsector.html.

Science, Technology and Innovation Policy (2013). Government of India: Ministry of Science and Technology. New Delhi.

Skinner, C., (2009). Challenging City/imaginaries: Street traders' struggle in Warwick Junction, Agenda. Special Issue on Gender and Poverty Reduction, vol. 81.

Thompson, J. (2010). Entrepreneurship enablers'-Their unsung and unquantified role in competitiveness and regeneration http://journals.sagepub.com/doi/10.1080/02690940903545406.

Zimmerer, T.W. \& Searborough, N.M. (2006). Essentials of Entrepreneurship and Small Business Management $4^{\text {th }}$ Edition. Prentice Hall of India, New Delhi.

Zvavahera, P. (2014). An evaluation of the effectiveness of performance management systems on service delivery in the Zimbabwean civil service. Journal of Management and Marketing Research. 